\title{
PERTARUNGAN SIMBOLIK DALAM WACANA BANTUAN KHUSUS MAHASISWA
}

\author{
M. Jazery \\ Fakultas Tarbiyah STAIN Tulungagung \\ e-mail: abahfuad69@yahoo.com
}

\begin{abstract}
This study aims to describe forms of, strategies in, and factors causing symbolic conflicts in the discourse of Special Aids for Students (SAS). The data sources were texts on SAS in mass media. This study employed the Critical Discourse Analysis (CDA) by Fairclough. The data were analyzed in three steps, i.e. text analysis (description), process analysis (interpretation) and socio-cultural practice analysis (explanation). The findings can be explained as follows. First, the forms of symbolic conflicts are the introduction and refusal of meaning, logic, perspective, and value. Second, the strategies of symbolic conflicts include making them subtle or vague and making them positive or natural. Third, the factors causing symbolic conflicts include differences in habits and social structure and those in discourse executors' interests.
\end{abstract}

Keywords: symbolic conflicts, critical discourse analysis, special aids for students

\section{PENDAHULUAN}

Kebijakan pemerintah SBY-JK menaikkan harga bahan bakar minyak (BBM) menyisakan persoalan yang berkepanjangan. Persoalan kenaikan harga BBM memang berdampak luas pada sendi-sendi kehidupan bangsa dan Negara. Sebagaimana sifat BBM yang mudah terbakar, maka ketika harga BBM naik terbakar pulalah emosi masyarakat Indonesia. Emosi tersebut dapat dilihat dari maraknya aksi demonstrasi penolakan naiknya harga BBM. Berbeda jika kenaikan harga terjadi pada minyak wangi, minyak oles, atau minyak rambut karena kenaikan harga minyak-minyak tersebut tidak akan menyeret kenaikan harga barang lainnya, khususnya sembilan bahan pokok (sembako).

Dampak kenaikan BBM terasa sekali bagi pelaku transportasi, seperti sopir angkot, sopir becak, dan kebanyakan masyarakat miskin Indonesia. Imbas kenaikan BBM terhadap tarif angkutan umum sebesar $20-25 \%$, begitu pula harga sembako meroket seolah tak terkendali. Masyarakat miskin yang selama ini sudah berat menaggung beban hidupnya harus menaggung lagi beban tambahan akibat kenaikan BBM. Oleh karena itu, demonstrasi menolak kenaikan harga BBM terjadi di manamana dan oleh siapa saja yang merasakan beban akibat kenaikan BBM. Mahasiswa dari berbagai perguruan tinggi mempelopori penolakan kenaikan harga BBM dengan berdemonstrasi yang terkadang harus bersitegang dengan aparat kepolisian. Bahkan, aparat kepolisisan yang terprovokasi oleh ulah demonstran menyerbu kampus Universitas Nasional di Jakarta. Ibu-ibu rumah tangga, ormas-ormas, dan LSM pun tidak ketinggalan menyuarakan penolakannya.

Menyikapi penolakan kebijakan menaikkan harga BBM, pemerintah SBY-JK mencari solusi yang dianggap 
tepat untuk meringankan beban rakyat miskin dan mahasiswa dari keluarga tidak mampu dengan membuat program bantuan langsung tunai (BLT) dan bantuan khusus mahasiswa (BKM). BLT diberikan kepada masyarakat miskin sebesar Rp 100.000 per bulan, sedangkan BKM diberikan kepada mahasiswa kurang mampu sebesar Rp 500.000 per semester. Di samping itu, pemerintah juga membuat program-program lain diperuntukkan bagi masyarakat miskin yang paling merasakan dampak langsung kenaikan harga BBM.

Namun, kebijakan pemerintah memberikan BLT dan BKM ditanggapi sinis oleh para pengamat dan mahasiswa. Fajrul Rahman, misalnya menganggap BKM sebagai bukti kepanikan pemerintah menghadapi demonstrasi mahasiswa karena takut diturunkan seperti ORBA dan ORLA. Sementara Budiyanto, presiden BEM UGM, menyatakan bahwa penyaluran BKM bagi mahasiswa miskin hanya pengalihan isu kenaikan harga BBM. Pemberian bantuan itu merupakan upaya sistematis untuk membungkam aspirasi mahasiswa. BLT dan BKM dimunculkan agar muncul kesan bahwa subsidi BBM dicabut untuk diberikan kepada warga miskin, termasuk mahasiswa miskin (http:/jurnalnasional.com/).

Jika fenomena di atas ditinjau dari kaca mata Bourdieu (1991) maka sesungguhnya dalam wacana BKM ini telah terjadi pertarungan simbolik. Pertarungan simbolik adalah sebuah persaingan untuk kekuasaan atas pelaku sosial yang lain, atas eksistensinya, pandangannya, persepsinya, danapresiasinya.Penyebabnya adalah perbedaan pandangan dunia (world view), perbedaan sudut pandang, dan perbedaan nilai-nilai. Tujuannya; mendapatkan kekuasaan memproduksi dan menunjukkan pandangan dunia yang paling diakui, yang paling dianggap benar, yang memiliki legitimi- tas. Singkatnya, pertarungan simbolik adalah pertarungan memperebutkan wacana dominant yang dianggap benar, tepat, dan diterima oleh masyarakat.

Wacana BKM telah menjadi arena pertarungan simbolik, yakni perebutan pemaknaan antara pemerintah di satu sisi, serta pengamat dan mahasiswa di sisi lain. Dalam hal ini pemerintah sebagai orthodoxa atau eksekutor wacana awal (prior discourse) sedangkan pengamat dan mahasiswa sebagai hethrodoxa atau eksekutor wacana tanding (counter discourse). Wacana awal mengatakan bahwa BLT dan BKM merupakan program pemerintah untuk membantu masyarakat miskin dan mahasiswa kurang mampu, sedangkan wacana tanding mengatakan bahwa BLT dan BKM merupakan upaya pemerintah untuk meredam kemarahan rakyat dan membungkam kritisisme mahasiswa.

Jika ditengok dengan analisis wacana kritis (AWK), maka apa yang terjadi merupakan perjuangan untuk mempertahankan kekuasaan, dominasi, dan penindasan oleh pemerintah. Sementara itu dari pihak lain, pengamat dan mahasiswa, hal ini merupakan perjuangan meruntuhkan kekuasaan, dominasi, dan kekerasan simbolik pemerintah. Masingmasing kelompok memperjuangkan kepentingannya dengan menggunakan simbol-simbol bahasa. Perjuangan tersebut dilakukan dengan strategi meconaisance; yakni eufimisasi dan sensorisasi.

Istilah pertarungan simbolik muncul dalam karya Pierre Bourdieu Language and Symbolic Power (1991). Dalam karya tersebut, Bourdieu mengkritik keras kelompok yang mencari kekuasaan kata-kata dalam kata-kata itu sendiri. Itu mustahil, katanya. Bagi Bourdieu, kata-kata mendapatkan kekuasaan dari penutur/eksekutornya. Karenanya Bourdieu tidak sependapat dengan kelompok strukturalis seperti Ferdinand de Saussure (langue-parole) 
dan Chomsky (competence-performance) yang masih mengeliminasi bahasa dari subjek yang berbicara dan konteks sosiohistoris yang melatarinya.

Jika bagi Saussure bahasa adalah fakta sosial, bagi Chomsky sebagai fakta psikologis, bagi Bourdieu bahasa adalah praktik sosial. Praktik sosial terjadi sebagai hasil dialektika antara internalisasi eksterior dengan eksternalisasi interior. Dengan kata lain, praktik bahasa merupakan interaksi dialektis antara pasar linguistik dengan habitus linguistik (Ibrahim, 2007). Pasar linguistik adalah arena dimana wacana-wacana termanifestasi, sedangkan habitus adalah kecenderungan praktik-praktik linguistik yang dimiliki oleh pelaku sosial. Dalam hal ini, Bourdieu banyak dipengaruhi oleh Wittgentein (1983) tentang konsep permainan bahasa (language game). Menurut Bourdieu (1991), otoritas yang dimiliki pelaku sosial bukanlah otoritas yang muncul begitu saja, tetapi merupakan inventasi sosial yang dicapai oleh si pelaku. Dengan demikian bahasa erat kaitannya dengan kekuasaan simbolik. Demikian juga dikemukakan oleh Fairclough (2001) bahwa bahasa berkaitan erat dengan kekuasaan. Melalui bahasa orang mendapatkan kekuasaan, dan dengan bahasa orang melanggengkan kekuasaanya.

Untuk mencapai kekuasaan simbolik, terjadilah pertarungan simbolik. Pertarungan simbolik adalah sebuah persaingan untuk kekuasaan atas pelaku sosial yang lain, atas eksistensinya, pandangannya, persepsinya, dan apresiasinya. Penyebabnya adalah perbedaan pandangan dunia (world view), perbedaan sudut pandang, dan perbedaan nilai-nilai. Tujuannya; mendapatkan kekuasaan memproduksi dan menunjukkan pandangan dunia yang paling diakui, yang paling dianggap benar, yang memiliki legitimitas.
Dalam pertarungan simbolik terjadi pertarungan wacana. Dalam pertarungan ada yang menang, ada yang kalah. Wacana yang menang menjadi dominan; doxa, sedang wacana yang kalah menjadi hetrodoxa. Pertarungan wacana dapat dilihat dengan jelas dalam kasus CNN dan Al-Jazeera dalam menyampaikan opini tentang perang Irak. Pertama-tama televisi CNN menguasai opini dunia dengan sewenang-wenang menggunakan pemilihan kata yang selalu menempatkan tentara Amerika pada posisi positif, dan tentara dan pejuang Irak dalam posisi negatif. Misalnya, berani $><$ brutal, hati-hati $><$ pengecut, setia $><$ fanatik, pahlawan $><$ teroris, dan lain-lain. Belakangan, muncul stasiun televisi Al-Jazeera yang meliput perang Irak dengan sudut pandang yang berbeda. Pertarungan simbolik pun dimulai. Opini-opini segera terbentuk, ada yang pro dan ada yang kontra. Ketika Al-Jazeera dianggap menggoyang kemapanan dominasi $\mathrm{CNN}$, Amerika pun membuat stasiun televisi tandingan seperti Midle East Television Network, AlArabia, dan Arab News Network.

Dalam pertarungan simbolik dibutuhkan kapital seperti ekonomi, budaya, sosial, dan simbolik. Kekuasaan simbolik dibangun dengan dua syarat, yaitu kapital simbolik dan strategi investasi simbolik (Bourdieu, 1991). Kepemilikan kapital simbolik yang tidak dikelola dengan strategi yang tepat akan melahirkan "inflasi kapital". Dalam hal ini Bourdieu banyak dipengaruhi oleh pemikiran Marxisme terutama tentang pertentangan antarkelas.

Dalam kehidupan sosial, wujud kekuasaan seringkali terpatri dalam gagasan politik formal, dan kekerasan diidentikkan dengan aktivitas fisik yang merugikan. Kekuasaan dan kekerasan masih diandaikan sebagai suatu interaksi yang terjadi dalam sebuah ruang kongkrit dengan sumber daya yang 
konkrit pula. Seiring dengan globlalisasi informasi dan teknologi, wujud kekuasaan dan kekerasan mengalami perubahan. Perwujudan relasi kekuasaan dan kekerasan pada era sekarang tidak lagi tampil dalam ruang kongkrit yang melibatkan aktivitas fisikal. Keduanya beroperasi dalam sebuah ruang representasi yang menjadikan sumber daya simbol sebagai kekuatan abstrak untuk menciptakan kebenaran yang berterima. Melalui representasi, sebuah realitas dapat dihadirkan melalui mobilisasi sistem simbol, baik bahasa, wacana, gambar, dan semacamnya (Fashri, 2007). Karenanya, memahami kinerja sebuah rezim politik atau aliran pemikiran tidak hanya dianalisa dari praktik pengambilan kebijakan, tetapi dapat pula dilihat dari pola-pola simbolik yang digunakannya, baik wacana yang diproduksi, tuturbahasa yang digunakan, hingga proses pencitraan yang menggambarkan respon terhadap persoalan-persoalan yang dihadapi.

Kekuasaan simbolik memiliki kemampuan untuk menyembunyikan bentuk aslinya, kekerasannya, dan kesewenang-wenangnya sehingga membuat orang lain terdominasi secara tidak sadar. Untuk mendapatkan dominasi itu, dibutuhkan mekanisme objektif, yaitu mekanisme yang membuat kelompok yang didominasi secara tidak sadar masuk ke dalam lingkaran diminasi dan menjadi patuh. Mekanisme ini oleh Bourdieu disebut kekerasan simbolik.

Kekerasan simbolik bekerja dengan mekanisme mecoinnaissance, penyembunyian kekerasan menjadi sesuatu yang "memang seharusnya demikian". Mekanisme ini berjalan dengan dua cara, yakni eufimisme dan sensorisasi. Eufimisme membuat kekerasan simbolik menjadi halus, tak dikenali, dan sensorisasi membuat kekerasan simbolik sebagai bentuk pelestarian nilai-nilai yang dianggap luhur.
Adalah lazim bagi setiap orde politik untuk menciptakan sistem simbol yang mencerminkan kekhasan kekuasaannya. Simbol mengandung kekuatan untuk membentuk wajah realitas. Orde Lama misalnya, memproduksi gagasan 'Nasakom' sebagai gugus simbolik yang bertujuan menyatukan kekuatan politik yang terpecah. Orde Baru membuat sistem simbol 'Pembangunan'. Era SBY-JK menjadikan wacana 'Good Gavernance' sebagai simbol untuk mendayung visi besar pemerintahannya.

Analisis wacana kritis (AWK) selalu melihat bahasa dala kaitannya dengan kekuasaan, terutama dalam pembentukan subjek dan berbagai tindakan representasi dalam masyarakat. Dalam AWK, wacana tidak hanya dideskripsikan berdasarkan aspek kebahasaan, tetapi juga dikaitkan dengan konteks makro wacana (Eriyanto, 2006). Wacana dilihat sebagai representasi kondisi sosial dalam masyarakat. Wacana dilihat dalam hubungannya dengan situasi, institusi, kepentingan, dan struktur sosial yang membentuknya.

AWK memiliki lima ciri pokok, yaitu (1) tindakan, (2) konteks, (3) kesejarahan, (4) kekuasaan dan hegemoni, dan (5) ideologi. Pertama, wacana dipandang sebagai sebuah tindakan, sebuah interaksi. Artinya, produsen wacana dipandang sedang melakukan interaksi dengan orang lain. Sebagai sebuah interaksi, wacana dipandang sebuah tindakan sadar yang memiliki tujuan tertentu, misalnya mempengaruhi orang lain, menyanggah pendapat, menolak ajakan, dan sebagainya.

Kedua, wacana dipandang sebagai sesuatu yang diproduksi, dimengerti, dan dianalisis pada konteks tertentu, yakni konteks mikro dan konteks makro. Konteks mikro terbatas pada konteks peristiwa tutur terjadi. Sedangkan konteks makro mencakup konteks social dan budaya. 
Ketiga, wacana dipandang dalam kaitannya dengan konteks social dan budaya tertentu. Ini berarti bahwa sebuah wacana tidak dapat dipahami tanpa melibatkan konteks sosio-budaya yang mebnyertainya. Salah satu konteks sosio-budaya yang penting adalah konteks histories (Foucault, 2003).

Keempat, wacana dipandang sebagai sesuatu yang bukan alamiah, wajar, dan netral (Piliang, 2001). Wacana merupakan bentuk pertarungan kekuasaan (Bourdieu, 1991). Kekuasaan yang dimaksud adalah kekuasaan dalam konsep budaya, yakni hubungan antara wacana dan masyarakat. Kekuasaan dipandang sebagai tindak pengontrolan, yakni orang atau kelompok yang memiliki kekuasaan berusaha mengontrol kelompok lain melalui wacana yang diproduksinya. Dengan demikian, analisis wacana tidak hanya menganalisis struktur wacana, melainkan juga analisis kekuatan dan kondisi social budaya yang melatari lahirnya wacana tersebut.

Kelima, wacana dipandang sebagai bentuk praktik ideologi (Van Dijk, 1997). Ideologi bersifat sosial dan berlaku secara internal. Bersifat sosial, karena ideologi membutuhkan kesepakatan dan kesepahaman antaranggota kelompok. Bersifat internal, karena dalam implementasinya ideologi memiliki daya kohesi dan koordinasi. Wacana merupakan representasi ideologi yang diproduksi oleh kelompok dominan agar ideologi yang diproduksi diterima sebagai kebenaran dan kewajaran. Karenanya, wacana tidak lagi sesuatu yang netral, melainkan memihak kepentingan ideologi produsennya.

Dalam pandangan analisis wacana kritis, setiap wacana harus dipandang tidak lahir dari ruang kosong, melainkan dari ruang yang penuh dengan muatan kepentingan. Setiap wacana mesti dicurigai memiliki kepentingan tertentu, baik ekonomi, politik, maupun lain- nya. Wacana dipandang sebagai sarana kelompok dominan untuk mengontrol dan menguasai kelompok lain. Karena itu, analisis wacana kritis tidak berhenti pada makna tektual, melainkan makna dalam konteks sosio-kulturalnya.

Selain tokoh-tokoh analisis wacana kritis, Fairclough, Wodak, dan van Dijk, Hidayat (2003) menyatakan bahwa dalam tradisi penafsiran wacana (hermeneutika) dikenal 'three master of prejudices', yakni Marx, Freud, dan Nietzche. Marx mengajak kita untuk mewaspadai kesadaran eksekutor wacana dan pembaca wacana yang sangat mudah dipengaruhi oleh status ekonomi dan politik. Nietzche mengajari kita bahwa pada dasarnya manusia memiliki keinginan untuk menguasai orang lain (the will to power). Dengan begitu, kita perlu waspada dalam memahami wacana yang diproduksi orang lain maupun orang yang memahami wacana tersebut karena di dalamnya pasti terbesit maksud untuk mempengaruhi dan menguasai orang lain. Sementara dari Freud, kita belajar bahwa bawah sadar setiap eksekutor wacana, juga pembacanya, pasti turut berperan dalam memandang dan menafsirkan realitas.

Penelitian ini bertujuan untuk mendeskripsikan dan menjelaskan pertarungan simbolik dalam wacana BKM. Tujuan tersebut dirinci dalam tujuan-tujuan khusus sebagai berikut (1) mendeskripsikan bentuk-bentuk pertarungan simbolik dalam wacana BKM, (2) mendeskripsikan strategi yang digunakan dalam pertarungan simbolik dalam wacana BKM, dan (3) menjelaskan faktor-faktor yang menyebabkan terjadinya pertarungan simbolik dalam wacana BKM.

\section{METODE}

Pertarungan simbolik merupakan bentuk penggunaan bahasa yang penuh dengan kepentingan, yakni kepentingan 
menguasai, mendominasi, dan mempengaruhi kelompok lain. Karena itu, pilihan kata, struktur kalimat senantiasa dicermati memiliki makna terselubung. Untuk dapat memberikan eksplanasi tentang makna-makna tersebut diperlukan AWK. Hal ini disebabkan Bourdieu sebagai penggagas pertarungan simbolik belum memiliki perangkat analisis yang jelas. Analisis data dilakukan dengan pendekatan AWK model Fairclough (1997) yang meliputi tiga dimensi, yakni dimensi teks, praktik kewacanaan, dan praktik sosiokultiural. Dengan demikian analisis data dilakukan dengan tiga langkah, yakni (1) analisis teks (deskripsi), (2) analisis pemrosesan (interpretasi), dan (3) analisis praktik sosio-kultural (eksplanasi).

\section{HASIL DAN PEMBAHASAN Bentuk Pertarungan Simbolik}

Pertarungan simbolik dalam wacana BKM ini memiliki dua bentuk, yakni (1) hanya mengenalkan satu makna, logika, perspektif, dan nilai tertentu, dan (2) menolak makna, logika, perspektif, dan nilai lain.

Hanya mengenalkan satu makna, logi$k a$, perspektif, dan nilai tertentu

Bagi pemerintah, pemberian BKM murni bertujuan untuk meringankan beban masyarakat miskin mahasiswa tidak mampu yang terkena dampak langsung dari kenaikan harga BBM. Program ini tidak dimaksudkan untuk meredam gejolak penolakan naiknya harga BBM. Wacana berikut merupakan pernyataan Andi Malarangeng sebagai juru bicara presiden:

Program pemerintah saat ini adalah mensubsidi langsung rakyat miskin, sedangkan sebelumnya berupa subsidi barang. Ini lucu kalau ada orang yang menentang BLT. Emang dia yang miskin. Yang miskin mau datang berduyun- duyun dan antre (http:///jurnalnasional.com/).

Wacana di atas hanya mengenalkan satu makna dan logika. Makna yang dikenalkan adalah bahwa BLT dan BKM merupakan bentuk subsidi langsung bagi rakyat miskin. Logika yang dikenalkan adalah jika rakyat miskin yang disubsidi, maka tidak mungkin mereka menolak. Buktinya, mereka "datang berduyun-duyun dan antre". Jadi yang menolak pasti bukan rakyat miskin. Karenanya "lucu" kalau ada yang menentang BLT. Karena rakyat miskin dan mahasiswa miskin yang terkena dampak langsung kenaikan harga BBM sudah dibantu. Dengan kata lain, pemerintah ingin menyatakan bahwa kenaikan harga BBM ini untuk mensubsidi rakyat dan mahasiswa miskin.

Wacana di atas mendapat tandingan dari kelompok hethrodoxa, yakni pengamat dan mahasiswa. Bagi mereka, program BLT dan BKM merupakan upaya pemerintah untuk merebut simpati rakyat dan mahasiswa miskin. Bahkan, dikatakan bahwa program BKM merupakan upaya menyuap atau menyogok mahasiswa agar mereka bungkam tidak protes dan demo lagi. Wacana berikut merupakan kontra wacana terhadap wacana di atas. Wacana yang diyatakan oleh Budiayanto, presiden BEM UGM, berikut juga hanya mengenalkan satu makna dan logika.

Kalau pemerintah serius membantu mahasiswa miskin, seharusnya BKM diberikan sebelum harga BBM naik. Jangan jadi pahlawan kesiangan. Ini hanya pengalihan isu dari persoalan besar kenaikan BBM. Kemudian dimunculkan kesan subsidi diberikan kepada warga miskin termasuk mahasiswa. Polisi seharusnya menjaga jalannya demonstrasi, bukan malah menyerang 
dan menganiaya mahasiswa (VHRmedia.com, Yogyakarta).

Pada wacana di atas, program BKM ditolak dengan mengemukakan seharusnya BKM diberikan sebelum harga BBM naik. Membantu warga dan mahasiswa miskin adalah kewajiban pemerintah meskipun harga BBM tidak naik. Karena bantuan baru diprogramkan setelah rakyat miskin betul-betul menjerit, mahasiswa menuduh pemerintah sebagai pahlawan kesiangan. Artinya, apa yang dilakukan pemerintah hanyalah untuk mencari muka karena semuanya sudah terlambat. Pengenalan satu makna, logika, dan perspektif juga dilakukan dalam menanggapi aksi polisi yang menyerang kampus UNAS Jakarta dengan mengatakan "Polisi seharusnya menjaga jalannya demonstrasi, bukan malah menyerang dan menganiaya mahasiswa". Padahal polisi mesti punya alasan sendiri mengapa menyerang dan menganiaya mahasiswa, mungkin berbuat anarkis dalam berdemo.

\section{Menolak makna, logika, perspektif, dan nilai lain}

Di samping hanya mengenalkan satu makna, logika, dan perpektif, pertarungan simbolik dalam wacana BKM juga menggunakan bentuk menolak makna, logika, dan perspektif lain. Mendiknas Bambang Sudibyo mengatakan sebagai berikut:

Bantuan Khusus Mahasiswa (BKM) murni sebagai bagian dari kompensasi kenaikan BBM dari pemerintah khusus di bidang pendidikan, sebab dengan aanya kenaikan BBM akan berpengaruh pada biaya kebutuhan mahasiswa, seperti buku, kos, dan transportasi. Pemerintah tidak akan memaksakan bagi mahasiswa yang mau menerima atau tidak (http:/// www.tempointeraktif.com).
Wacana di atas merupakan wacana awal (prior discourse) sebagai antisipasi terhadap penolakan BKM oleh mahasiswa. Wacana tersebut secara jelas ditujukan kepada mahasiswa yang selama ini getol mengkampanyekan penolakan terhadap kenaikan harga BBM. Wacana di atas diawali dengan pernyataan bahwa tidak ada kepentingan apa pun di balik BKM dengan mengatakan BKM murni sebagai bagian kompensasi kenaikan BBM khusus untuk bidang pendidikan. Sebagai antisipasi tehadap penolakan mahasiswa, sang menteri pun menyatakan pemerintah tidak akan memaksakan bagi mahasiswa yang mau menerima atau tidak. Wacana di atas tidak menawarkan alternatif logika lain bagimana jika mahasiswa tidak mau menerima BKM. Dengan kata lain, wacana di atas menolak semua maka dan logika lain, kecuali makna dan logika eksekutornya.

Wacana berikut merupakan wacana tandingan terhadap wacana di atas. Wahyono menolak logika yang dikenalkan oleh sang Menteri. Dengan lantang berani, Wahyono yang mantan aktivis mahasiswa ini mengatakan bahwa BKM adalah aksi sogok oleh pemerintah kepada mahasiswa untuk menutup kritisitas mahasiswa.

Aksi sogok atau suap kembali dilakukan dan dipamerkan oleh pemerintah SBY-JK tanpa rasa bersalah dan malu. Setelah menyuap rakyat miskin dengan BLT, giliran menyuap mahasiswa dengan BKM dalam rangka menyumbat celah kritisitas mahasiswa peduli rakyat terhadap kebijakan kenaikan harga BBM bikinan Pemerintah RI yang telah berideologi kapitalis Pasar Dunia (http:///www.apakabar.ws ).

Pada wacana di atas, eksekutor wacana berusaha menolak BKM dengan mengemukakan bahwa BLT dan 
BKM merupakan aksi sogok atau suap pemerintah. Tujuannya untuk menyumbat celah kritisitas mahasiswa. alasannya, karena yang diberi bantuan khusus hanya mahasiswa bukan semua siswa termasuk siswa SD sampai SMU. Karena yang berdemo hanya mahasiswa, maka yang disuap hanya mahasiswa. Andai siswa SD sampai SMU juga ikut demo menolak kenaikan BBM, maka mereka pun juga akan mendapat bantuan (baca: suap) yang sama. Mahasiswa paham bahwa BKM identik dengan suap atau upaya untuk mengbungkam mahasiswa. BKM diberikan kepada mahasiswa dari keluarga miskin agar bias juga dipergunakan untuk membujuk orang tua mereka yang juga miskin yang sedang menangis pilu akibat beban ekonomi yang harus ditanggungnya. Pada wacana di atas, eksekutor menolak alternative makna, logika, atau perspektif lain yang ditawarkan oleh eksekutor wacana awal.

\section{Strategi Pertarungan Simbolik dalam BKM}

Pertarungan simbolik dalam wacana BKM dilakukan dengan strategi meconaissance, yakni eufemisasi dan sensorisasi. Eufimisasi dilakukan dengan penghalusan dan penyamaran makna, sedangkan sensorisasi dilakukan dengan pelogisan serta pemositifan dan pewajaran.

\section{Penghalusan dan Penyamaran}

Salah satu strategi yang di gunakan dalam pertarungan simbolik dalam wacana BKM adalah penghalusan dan penyamaran makna. Strategi ini digunakan oleh pemerintah SBY-JK untuk mensukseskan program menaikkan harga BBM agar diterima oleh masyarakat. Karena itu simbol yang digunakan adalah "bantuan" bukan "sogokan", "suap", atau "duit damai". Wacana dari mendiknas Bambang Sudibyo dan
Balkan Kaplale (anggota DPR RI fraksi Demokrat) berikut patut diperhatikan.

BKM merupakan upaya mengurangi angka "drop out" akibat naiknya harga BBM yang berpengaruh juga terhadap naiknya harga kebutuhan hidup lainnya. Soal pendidikan menjadi prioritas utama karena merekalah yang nantinya akan membangun negeri ini (http://jurnalnasional.com).

BKM merupakan upaya untuk mendukung peningkatan sumber daya manusia generasi penerus bangsa (http://jurnalnasional.com).

Pada wacana di atas, sang menteri sengaja menggunakan strategi penghalusan makna BKM dengan upaya mengurangi angka "drop out". Makna tersebut dikuatkan lagi dengan alasan bahwa pemerintah memprioritaskan pendidikan karena masa depan bangsa dan Negara ada pada generasi muda dan anak-anak. Begitu juga sang DPR juga neguatkan bahwa BKM bertujuan mulia untuk meningkatkan kualitas SDM generasi penerus bangsa. Padahal jika dicermati, tujuan sebenarnya adalah membuat kebijakan menaikan harga BBM oleh pemerintah mendapat dukungan dan diterima masyarakat Indonesia. Hal ini didasarkan fakta bahwa mendiknas dan sang DPR fraksi Demokrat adalah bagian dari pemerintah. Karena itu, wacana yang dilontarkan tentu memihak kepentingan pemerintah, yakni membuat masyarakat Indonesia, khususnya dunia pendidikan, memahami dan menerima kebijakan pemerintah menaikkan harga BBM.

Wacana di atas mendapat tandingan dari kelompok lain. Wacana tersebut juga menggunakan strategi sama, yakni penghalusan dan penyamaran makna. Wacana berikut dikemukakan oleh Yasin Kara, anggota DPR RI dari fraksi PAN. 
Selain memberikan bantuan khusus mahasiswa (BKM) diperlukan kebijakan membebaskan biaya pendidikan dari sekolah dasar (SD) sampai ke jenjang menengah atas (SMA) (http://Jurnalnasional.com).

Pada wacana di atas eksekutor menghaluskan makna penolakan BKM dengan cara mengemukakan bahwa yang ditolak bukan BKM-nya, tapi harus ada pemerataan bantuan kepada semua generasi penerus bangsa termasuk siswa SD sampai SMA karena mereka juga membutuhkan bantuan untuk tetap bias meneruskan pendidikannya. Penolakan halus sang DPR dari fraksi PAN di atas dapat dimaklumi karena ia merupakan bagian dari kelompok pendukung pemerintah yang tidak setuju dengan kebijakan kmenaikkan harga BBM.

\section{Pelogisan}

Kalangan pemerintah berpendirian bahwa kebijakan memberikan BKM sebagai kompensasi kenaikan harga BBM merupakan kebijakan yang harus didukung karena merekalah yang terkena dampak langsung dari kenaikan harga BBM. Pemerintah menghimbau agar rakyat mengencangkan ikat pinggang. Bagi warga dan mahasiswa miskin akan diberikan bantuan. Pemerintah meminta rakyat memahami niat baik pemerintah. Berikut ini wacana yang dilontarkan oleh pemerintah melalui mendiknas.

Bantuan Khusus Mahasiswa (BKM) murni sebagai bagian dari kompensasi kenaikan BBM dari pemerintah khusus di bidang pendidikan, sebab dengan adanya kenaikan BBM akan berpengaruh pada biaya kebutuhan mahasiswa, seperti buku, kos, dan transportasi.... (http://www. tempointeraktif.com).
Wacana di atas berusaha melogiskan BKM dengan mengkaitkan langsung dengan beban yang harus ditanggung mahasiswa akibat kenaikan harga BBM. Karena itu logislah kebijakan memberikan BKM untuk membantu mengurangi beban mahasiswa. Tidak bisa dipungkiri bahwa salah satu dampak dari kenaikan BBM adalah bertambahnya beban hidup bagi kalangan mahasiswa, baik untuk kebutuhan hidup sehari-hari seperti biaya makan, sewa kost, dan ongkos transportasi, maupun untuk memenuhi biaya kuliah yang tentunya juga naik. Karenanya, BKM merupakan kebijakan yang dapat dipertanggungjawabkan.

Berbeda dengan pemerintah, kelompok pengamat dan mahasiswa menganggap bahwa BLT dan BKM adalah bentuk upaya penyuapan oleh pemerintah kepada masyarakat dan mahasiswa miskin. Penyuapan tersebut dilakukan untuk menyumbat dan membungkam daya kritis, atau mengajak damai mahasiswa. Wacana tandingan berikut patut diperhatikan.

Lagi-lagi rakyat kembali pada posisi "objek penderita", "korban", dan "tumbal pemujaan materi". BLT bukan saja singkatan dari Bantuan Langsung Tunai, melainkan Bantuan Langsung Tewas. Umpama baru naik sepeda hibahan tapi segera diseruduk konvoi truk tronton berkecepatan tinggi yang memuat barangbarang dagangan. SBY yang pernah kuliah hingga mendapat gelar Doktor pasti mengerti soal buku dan kisaran harganya. Sangat disayangkan SBY bisa menangis gara-gara "Ayat-ayat Cinta" yang direkayasa dalam film, tetapi tidak pernah mampu menangis atas penderitaan rakyat di depan matanya (http://www.apakabar.ws). 
Wacana di atas merupakan tandingan pelogisan wacana yang dilontarkan oleh pemerintah. Dalam hal kenaikan BBM, rakyat selalu menjadi objek pen-derita. BLT pun diplesetkan menjadi Bantuan Langsung Tewas. Alasannya, BLT dan BKM hanya diberikan sebesar Rp 100.000 per bulan, itu pun hanya untuk tujuh bulan. Uang Rp 100.000 tentu tidak akan mampu menutup lonjakan harga yang harus ditanggung oleh warga dan mahasiswa miskin. Jadi penerima BLT dan BKM ibarat mendapat hibah sepeda tapi segera diseruduk konvoi truk tronton. Artinya, uang seratus ribu tidak akan mampu mengimbangi kenaikan harga yang sebesar tronton dan berkecepatan tinggi. Sehingga logislah jika mahasiswa atas nama rakyat menolak kebijakan pemerintah menaikkan harga BBM. Logis pula jika BKM dimaknai uang sogok atau uang damai untuk meredam demodemo mahasiswa.

\section{Pemositifan dan Pewajaran}

Pemerintah menganggap kebijakan memberikan BLT dan BKM merupakan suatu bentuk keprihatinan pemerintah atas kenaikan harga barang-barang kebutuhan akibat kenaikan harga BBM. Untuk membuat program BLT dan BKM murni kompensasi akibat kenaikan harga BBM, pemerintah melontarkan wacana yang membuat program tersebut dianggap sebagai sesuatu yang positif dan wajar. Wacana yang dilontarkan Ihsan Modjo, dosen Fakultas Ekonomi Universitas Airlangga, berikut patut diperhatikan.

Secara teoretis, sebagaimana yang dipostulasikan dalam The Second Welfare Theorem pada kajian ilmu ekonomi mikro, bantuan langsung melalui cash transfer akan lebih efektif sebagai wahana distribusi pendapatan, daripada subsidi tidak langsung lewat intervensi harga. Alasannya, selain bersifat gebyah uyah (one size fits all) sehingga cenderung salah sasaran, bantuan tidak langsung, sebagaimana halnya subsidi BBM, akan mendistorsi peran alokasi harga, yang berujung pada maraknya inefisiensi serta pasar gelap (Suara Pembaruan).

Pada wacana di atas, eksekutor melakukan pemositifan dan pewajaran dengan memberikan alasan bahwa subsidi BBM akan mendistorsi peran alokasi harga, yang berujung pada inefisiensi serta pasar gelap. Subsidi harga BBM cenderung salah sasaran karena yang menikmati justru orang kaya yang lebih membutuhkan BBM ketimbang warga miskin. Di samping itu, tidak disangkal lagi bahwa maraknya penggelapan BBM illegal ke luar negeri dikarenakan harga BBM di luar negeri lebih tinggi. Dengan demikian bantuan langsung dalam bentuk BLT dan BKM lebih efektif sebagai wahana distribusi pendapatan. Hal senada juga disampaikan oleh Mari Elka Pangestu, menteri perdagangan.

Haruslah dipahami terlebih dahulu mengapa pemerintah menempuh kebijakan semacam itu. Yakni, untuk meredam gejolak atas kebijakan kenaikan harga BBM, khususnya minyak tanah, yang sangat dibutuhkan bagi warga miskin. Selama ini pola subsidi yang dijalankan sudah jelas salah sasaran, karena lebih banyak dinikmati oleh kelompok masyarakat menengah ke atas. Atas dasar itulah sekarang ingin langsung dibagikan kepada rakyat miskin dalam bentuk uang tunai (http://www.tempointeraktif.com).

Wacana di atas mendapat tandingan wacana dari kelompok lain. Wacana tandingan juga menggunakan strategi pemositifan dan pewajaran. Untuk membuat penolakan BLT dan BKM sebagai sesuatu yang positif dan wajar 
karena dibalik program tersebut patut dicurigai niat busuk pemerintah.

SBY yang pernah kuliah hingga mendapat gelar Doktor pasti mengerti soal buku dan kisaran harganya. Sangat disayangkan SBY bisa menangis gara-gara Ayat-ayat Cinta yang direkayasa dalam film, tetapi tidak pernah mampu menangis atas penderitaan rakyat miskin di depan matanya (http://www.apakabar.ws).

Pada wacana tandingan di atas, pemositifan dan pewajaran dilakukan dengan cara membandingkan keharuan Presiden ketika nonton film Ayat-ayat Cinta dengan ketidakpekaannya melihat realitas rakyat yang menderita gara-gara kenaikan BBM. Berapa jumlah anak-anak yang terkena gizi buruk (di NTT, Indramayu, Ciamis, dll) akibat orang tuanya miskin. Sehingga wajar jika mahasiswa atas nama rakyat menolak kebijakan pemerintah menaikkan harga BBM. Jadi, wajar pula jika BKM dimaknai uang damai atau duit tutup mulut.

\section{Penyebab Pertarungan dalam Wacana BKM}

Pertarungan simbolik dalam wacana BKM ini disebabkan oleh (1) perbedaan habitus dan struktur sosial eksekutor wacana, dan (2) perbedaan kepentingan eksekutor wacana.

\section{Perbedaan Habitus dan Struktur Ek- sekutor Wacana}

Dalam pandangan Bourdieu (1991), bahasa merupakan praktik sosial. Praktik sosial terjadi sebagai hasil dialektika antara internalisasi eksterior dengan eksternalisasi interior. Apabila interior itu adalah pelaku sosial dan semua yang melekat pada dirinya yang dibentuk oleh habitus, sedangkan eksterior adalah struktur objektif yang ada di luar diri pelaku sosial, yaitu arena, maka praktik sosial dengan sendirinya tidak otonom karena merupakan produk interaksi antara pelaku sosial dan struktur sosial. Dengan kata lain, praktik bahasa merupakan interaksi dialektis antara pasar linguistik dengan habitus linguistik. Pasar linguistik adalah arena dimana wacana-wacana termanifestasi, sedangkan habitus adalah kecenderungan praktik-praktik linguistik yang dimiliki oleh pelaku sosial.

Berdasarkan uraian di atas, maka wajarlah jika wacana yang dilontarkan oleh kelompok orthodoxa berbeda dengan wacana yang dilontarkan oleh kelompok hetrhodoxa. Kelompok orthodoxa dibentuk oleh habitus linguistik yang berbeda dengan habitus linguistik kelompok hetrhodoxa. Habitus merupakan kecenderungan-kecenderungan praktik linguistik yang tertanam dalam diri pelaku sosial, baik yang berhubungan dengan perilaku fisik, maupun persepsi dan logika bahasanya. Kelompok orthodoxa dibentuk oleh habitus pemerintahan dan kekuasaan sehingga persepsi dan logika bahasanya khas sebagai orang pemerintahan yang berada dalam posisi mendominasi. Sementara kelompok hetrhodoxa dibentuk oleh habitus kampus dan non-pemerintahan sehingga persepsi dan logika bahasanya khas sebagai orang yang dikuasai dan didominasi yang tidak menginginkan kemapanan dominasi pemerintah.

Begitu juga jika dilihat dari struktur sosial yang membentuk pelaku sosial. Kelompok orthodoxa menduduki struktur pemerintahan dan kekuasaan sehingga wacana yang dilontarkan khas sebagai wacana orang pemerintahan yang berada dalam posisi menguasai dan mendominasi. Tujuan dari setiap wacana yang dilontarkan adalah untuk melestarikan dan mempertahankan dominasi untuk mengontrol wacana yang legitimate yang selama ini mereka 
miliki. Sementara kelompok hetrhodoxa berada kampus dan non-pemerintahan sehingga wacana yang diproduksi khas sebagai orang yang dikuasai dan didominasi. Tujuannya; mendobrak kemapanan dominasi penguasa agar terjadi perubahan.

\section{Perbedaan kepentingan eksekutor wa- cana}

Dalam pandangan analisis wacana kritis, setiap wacana harus dipandang tidak lahir dari ruang kosong, melainkan dari ruang yang penuh dengan muatan kepentingan. Setiap wacana mesti dicurigai memiliki kepentingan tertentu, baik ekonomi, politik, maupun lainnya. Wacana dipandang sebagai sarana kelompok dominan untuk mengontrol dan menguasai kelompok lain. Dengan kata lain, tidak ada wacana yang murni atau polos. Setiap wacana memiliki muatan kepentingan.

Dalam pandangan Marx, kesadaran eksekutor wacana dipengaruhi oleh status ekonomi dan politik. Bukan kesadaran yang membentuk realitas, tetapi realitaslah yang membentuk kesadaran manusia. Jadi, kelahiran wacana jenis apapun tidak luput dari pengaruh kepentingan ekonomi dan politik. Wacana yang diproduksi oleh penguasa atau orang yang bersahabat dengan penguasa, yang dimanjakan oleh harta dan fasilitas ekonomi pasti berbeda dari wacana yang diproduksi oleh mahasiswa yang kritis tarhadap istana.

Sedangkan Nietzche mengajari kita bahwa pada dasarnya manusia memiliki keinginan untuk menguasai orang lain (the will to power). Dengan begitu, kita perlu waspada dalam memahami wacana yang diproduksi orang karena di dalamnya pasti terbesit maksud untuk mempengaruhi dan menguasai orang lain. Seorang eksekutor wacana ingin agar dirinya dikatan hebat dan pendapatnya diikuti orang banyak.
Karenanya, wacana yang diproduksi oleh penguasa pasti berbeda dari wacana yang diproduksi oleh orang yang dikuasai.

Karena kepentingan yang berbeda, para eksekutor wacana berusaha berebut legitimasi kebenaran melalui wacana yang diproduksinya. Dalam perebutan kebenaran tersebut terjadi pertarungan wacana. Masing-masing pihak mengklaim bahwa wacana yang diproduksinya yang paling benar sementara wacana produksi pihak lain salah. Karena itu, karena perbedaan kepentingan, wacana yang diproduksi pemerintah selalu ditandingi oleh mahasiswa. Sehingga, BLT yang oleh pemerintah dimaknai "Bantuan Langsung Tunai", atau "Barokah Langsung Turun", oleh mahasiswa dimaknai "Bantuan Langsung Tewas". BKM yang oleh pemerintah dimaknai "Bantuan Khusus Mahasiswa", oleh mahasiswa dimakna "uang sogok", "suap", atau "duit damai".

\section{SIMPULAN}

Berdasarkan uraian di atas, penulis menarik beberapa simpulan sebagai berikut. Pertama, wacana bantuan khusus mahasiswa (BKM) telah menjadi arena pertarungan simbolik antara pemerintah (orthodoxa) dengan pengamat dan mahasiswa (hetrhodoxa). Wacana-wacana yang dilontarkan pemerintah mengandung makna bahwa BKM adalah bantuan untuk mahasiswa miskin sebagai kompensasi dari kenaikan harga BBM. Pada sisi lain, wacana-wacana tandingan yang diproduksi oleh mahasiswa mengusung makna bahwa BKM merupakan strategi "suap" pemerintah untuk menyumbat sikap kritis mahasiswa.

Kedua, pertarungan simbolik antara pemerintah dengan pengamat dan mahasiswa dilakukan dengan dua bentuk, yaitu (1) hanya mengenalkan makna, logika, perspektif, dan nilai, dan 
(2) menolak makna, logika, perspektif, dan nilai lain. Makna yang dilontarkan pemerintah selalu ditolak oleh mahasiswa, sebaliknya makna yang diperjuangkan oleh mahasiswa selalu ditolak oleh pemerintah. Pertarungan simbolik dilakukan dengan menggunakan strategi meconaisance, yakni sensorisasi dan eufimisasi. Sensorisasi dilakukan dengan pelogisan, pemositifan, dan penegasian. Sedangkan eufimisasi dilakukan dengan penghalusan dan penyamaran.

Ketiga, pertarungan simbolik dalam wacana BKM terjadi karena perbedaan habitus dan struktur sosial serta perbedaan kepentingan eksekutor wacana. Pemerintah yang hidup di habitus dan struktur kekuasaan berusaha selalu mengontrol, menguasasi, dan mendominasi pihak lain melalui produksi wacananya. Sebaliknya, pengamat dan mahasiswa hidup di habitus dan struktur non-pemerintah ingin mendobrak dan melepaskan diri dari kekuasaan, dominasi pemerintah melalui wacana yang diproduksinya. Di sinilah jika ditinjau dari analisis wacana ktiris, patut dicurigai ada kepentingan-kepentingan tertentu di balik keinginan pemerintah untuk memberikan BKM dan kengototan mahasiswa untuk menolaknya.

\section{UCAPAN TERIMA KASIH}

Artikel ini diangkat dari penelitian mandiri swadana yang dilaksanakan pada tahun 2008. Ucapan terima kasih disampaikan kepada para mahasiswa yang telah membantu pelakasanan pengumpulan data dan kepada mitra sejawat yang telah membantu kegiatan verifikasi dan triangulasi data dan hasil penelitian.

\section{DAFTAR PUSTAKA}

Bourdeiu, Pierre. 1991. Language and Symbolic Power. Cambridge, Massachusetts: Harvard University Press.

Eriyanto. 2006. Analisis Wacana: Pengantar Analisis Teks Media. Yogyakarta: LKiS Pelangi Aksara.

Van dijk, Teun. A. 1997. "Political Discourse and Political Cognition". Makalah Congress Political Discourse, Aston University. Diakses dari http://www.hum.uva.nl/ teun.

Fairclough, Norman. 1997. Discourse and Social Change. Cambridge: Polity Press.

Fairclough, Norman. 2001. Language and Power. England: Pearson Education Limited.

Fashri, Fauzi. 2007. Penyingkapan Kuasa Simbol: Apropriasi Reflektif Pemikiran Pierre Bourdieu. Yogyakarta: Juxtapose.

Faucoult, Michel. 2003. Kritik Wacana Bahasa. Terjemahan Inyiak Ridwan Muzir. Yogyakarta: IRCiSod.

Hidayat, Komaruddin. 2003. Menafsirkan Kehendak Tuhan. Jakarta: Teraju.

Ibrahim, Abd. Syukur. 2007. "Teori-Teori Pengetahuan". Bahan Kuliah Tidak diterbitkan. Malang: PPS UM Malang.

Piliang, Yasraf Amir. 2001. Hiper-Realitas Media dan Kebudayaan: Kebenaran dalam Kegalauan Informasi. Yogyakarta: Penerbit Jalasutra

Wittgenstein, L. 1983. Philosophical Investigations. (trans). G.E.M. Ascombe. Basil Blackwell. Oxford. 